\title{
A New Growth Effecting Peptide of Bacillus Species from Soybean Cake
}

\author{
Toshikazu Chiyonobu, Katsuhisa Shrrai, Osao Adachi and Minoru Ameyama \\ Department of Agricultural Chemistry, Yamaguchi University, Yamaguchi, Japan \\ Received November 19, 1973
}

\begin{abstract}
A new peptide, which has a marked effect on the growth of Bacillus species, was purified from soybean cake by a procedure employing ammonium sulfate fractionation, and active charcoal-, DEAE-Sephadex A-25- and Sephadex gel-column chromatographies. The purified peptide gave a single band on paper electrophoresis. The peptide possessed the following properties: specific extinction $\left(E_{1 \mathrm{em}}^{1 \%}\right.$ at $\left.280 \mathrm{~nm}\right), 11.9$; N-terminal amino acid, glutamate; molecular weight, 8058; total number of amino acid, 70; chemical composition (\%), C, 49.12; $\mathrm{H}, 6.26 ; \mathrm{N}, 16.44$; and $\mathrm{S}, 2.34$; isoelectric point, $\mathrm{pH}$ 4.3. The hydrolyzed peptide had no stimulative effect on the growth of Bacillus species. Especially, those microorganisms belonging to the genera of Bacillus, Arthrobacter and Xanthomonas were remarkably sensitive to the peptide.
\end{abstract}

Recent investigations have shown that substances contained in soybean have a nutritional effect on the growth of bacteria; namely, an aqueous extract of soybean seeds, ${ }^{1}$ soy proteins $^{2)}$ and a peptide in soybean Miso ${ }^{31}$ stimulate the growth of Lactobacillus species, Clostridium perfringens, and Pediococcus halophilus, respectively. In the course of our investigation on the growth of aerobic bacteria, we also observed that the addition of soybean cake into a complete synthetic medium markedly stimulated the growth of Bacillus species.

The present paper deals with the purification and chemical properties of the purified peptide. The sensitivity of various microorganisms to the purified peptide is also presented in this paper.

\section{MATERIALS AND METHODS}

Chemicals. All of the chemicals used in this work were commercial products. Soybean cake was kindly supplied from Marukin Shôyu Co., Ltd., Japan.

Microorganisms. The microbial strains used in this work were supplied from the Laboratory of Applied Microbiology, Department of Agricultural Chemistry, Kyoto University (AKU) and Institute for Fermentation, Osaka (IFO). All of the strains used are listed in Table IV.
Culture and inoculum. Microorganisms were cultured at $30^{\circ} \mathrm{C}$ under continuous shaking. After testing commonly used nutrients of bacterial growth (e.g. vitamins, minerals, amino acids and bases), the composition of the basal medium used in this work was determined as follows: Glucose $4.0 \mathrm{~g}$, Na-glutamate $3.0 \mathrm{~g}, \quad\left(\mathrm{NH}_{4}\right)_{2} \mathrm{SO}_{4} 3.0 \mathrm{~g}, \quad \mathrm{KH}_{2} \mathrm{PO}_{4} 250 \mathrm{mg}, \mathrm{K}_{2} \mathrm{HPO}_{4}$ $750 \mathrm{mg}, \mathrm{MgSO}_{4} \cdot 7 \mathrm{H}_{2} \mathrm{O} 300 \mathrm{mg}, \mathrm{FeSO}_{4} \cdot 7 \mathrm{H}_{2} \mathrm{O} 30 \mathrm{mg}$, $\mathrm{NaCl} 10 \mathrm{mg}$, thiamine-HCl $400 \mu \mathrm{g}$, nicotinic acid $400 \mu \mathrm{g}$, Ca-pantothenate $400 \mu \mathrm{g}$, and $p$-aminobenzoate $100 \mu \mathrm{g}$ in 1 liter of distilled water. The $\mathrm{pH}$ was adjusted to 7.2. Samples containing active fractions were added to $2.5 \mathrm{ml}$ of the basal medium of double strength in a test tube, and the total volume was made up to $5 \mathrm{ml}$ with distilled water. After autoclaving at $115^{\circ} \mathrm{C}$ for $15 \mathrm{~min}$, each tube was inoculated with one drop of the inoculum suspension the optical density of which was prepared to be 0.5 at $660 \mathrm{~nm}$.

Measurement of microbial growth. The growth of microorganisms was determined turbidimetrically by reading the turbidity at $660 \mathrm{~nm}$ using a spectrophotometer of Hitachi model 124 or a Klett-Summerson model photoelectric colorimeter.

Bioautography. Growth-effecting substances on the paper chromatogram were bioautographically determined. To $250 \mathrm{ml}$ of the hot basal medium containing 1.5 per cent of agar, $10 \mathrm{ml}$ of an inoculum suspension ( $B$. cereus) was added. The mixture was immediately poured on glass plates and cooled. The samples containing growth-effecting substances were paper-chromatographed (Toyo Roshi No. 51) in a mixture of phenol and water $(4: 1)$. The developed papers were dried, cut off as paper ribbons and placed 
on inoculated agar plates prepared as mentioned above. The plates were incubated at $30^{\circ} \mathrm{C}$ for about $20 \mathrm{hr}$ until turbid spots owing to growth-effecting substances appeared on the plates.

Other measurements. Methods of molecular weight-determination and others will be referred to in each corresponding section.

\section{RESULTS}

Purification of growth-effecting substance

All operations were carried out at $5^{\circ} \mathrm{C}$ throughout the purification procedures.

Step I. Preparation of extracts from soybean cake

Extracts from soybean cake were prepared by the following procedures. Soybean cake $(2 \mathrm{~kg})$ was extracted with 10 liters of boiling water for $30 \mathrm{~min}$. Then the extract was filtered or centrifuged to separate insoluble materials. The clear extract was adjusted to pH 4 with $6 \mathrm{~N} \mathrm{HCl}$ to remove the globlin fraction, and the precipitate was discarded by continuous-flow-centrifuge at $9000 \times g$. The supernatant containing growth-effecting substances was treated as follows.

\section{Step II. Charcoal column chromatography}

The absorbent equilibrated with distilled water was packed into a column $(5 \times 50 \mathrm{~cm})$. The supernatant solution was adjusted to $\mathrm{pH} 7$ with $6 \mathrm{~N} \mathrm{NaOH}$ and placed on the top of the column. The column was thoroughly washed with 5 liters of distilled water. The absorbed active fractions were eluted with $50 \%$ ethanol containing $0.2 \% \mathrm{NH}_{3}$ and then the eluates were combined together to give $600 \mathrm{ml}$ of the solution. The ammonia and ethanol in the active fractions were completely evaporated off in vacuo at $50^{\circ} \mathrm{C}$ and the dried sample was dissolved in $100 \mathrm{ml}$ of distilled water.

\section{Step III. First DEAE-Sephadex A-25 column chromatography}

The absorbent equilibrated with $0.01 \mathrm{~m}$ ammonium carbonate, $\mathrm{pH} 8.0$, was packed into a column $(5 \times 50 \mathrm{~cm})$. The dissolved sample was placed on the top of the column, and then the column was thoroughly washed with 2 liters of $0.01 \mathrm{M}$ ammonium carbonate. The absorbed sample was stepwisely eluted with $0.1,0.2$ and $0.5 \mathrm{M}$ ammonium carbonate solutions. As shown in Fig. 1, the active fractions were eluted with $0.2 \mathrm{M}$ ammonium carbonate and the eluates were combined to give $400 \mathrm{ml}$. The ammonium carbonate in the active fractions was completely evaporated off in vacuo at $50^{\circ} \mathrm{C}$.

\section{Step IV. Ammonium sulfate fractionation}

The dried sample was dissolved in $100 \mathrm{ml}$ of distilled water. To the dissolved solution was added $17.6 \mathrm{~g}$ of solid ammonium sulfate up to $30 \%$ saturation under mechanical stirring: The $\mathrm{pH}$ adjusted to 7.0 with $10 \%$ ammonium hydroxide solution. After standing overnight, the precipitate was removed by

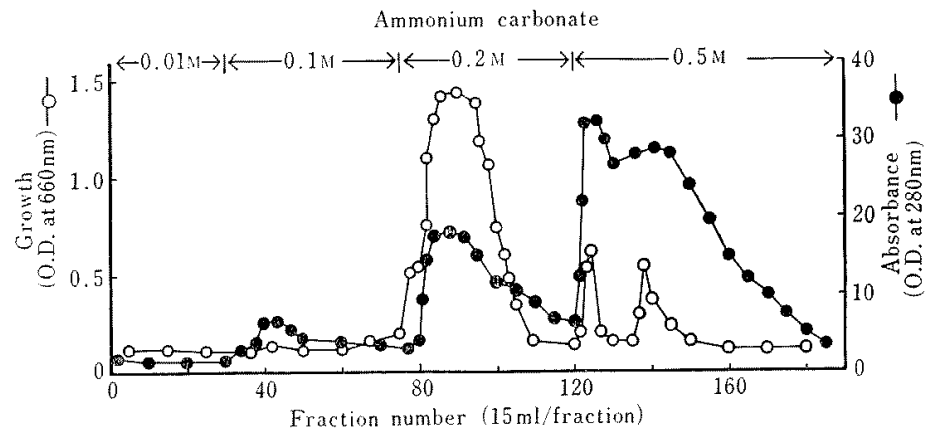

FIG. 1. Chromatography of Growth Effecting Substance on DEAE-Sephadex A-25.

Chromatography was performed as stated in the text, and the activity was bioassayed under the standard assay conditions. 
centrifugation at $9000 \times g$ for $20 \mathrm{~min}$. The ammonium sulfate concentration of the supernatant solution was then increased to $60 \%$ saturation by addition of solid ammonium sulfate. The precipitate was collected by centrifugation at $9000 \times g$ for $10 \mathrm{~min}$ after standing overnight and dissolved in a small volume of distilled water.

\section{Step V. Sephadex G-25 gel filtration}

The dissolved solution was subjected to Sephadex gel filtration. The absorbent equilibrated with distilled water was packed into a column $(3.5 \times 180 \mathrm{~cm})$. The sample was eluted with distilled water and the active fractions were combined to give $100 \mathrm{ml}$ of the solution.

\section{Step VI. Second DEAE-Sephadex A-25} column chromatography

The eluted active fractions were rechromatographed using a column $(2 \times 30 \mathrm{~cm})$ by means of the same procedure as described in the first DEAE-Sephadex A-25 column chromatography. A linear gradient elution was performed by a two chambers system with $200 \mathrm{ml}$ of $0.01 \mathrm{M}$ ammonium carbonate in the first chamber and $200 \mathrm{ml}$ of $0.3 \mathrm{M}$ ammonium carbonate in the second one. The active fractions were eluted with $0.2 \mathrm{M}$ ammonium carbonate and the eluates were combined to give $60 \mathrm{ml}$ of the solution. The ammonium carbonate in the active fractions was completely evaporated off in vocuo at $50^{\circ} \mathrm{C}$, and then the dried sample was dissolved in a small volume of distilled water.

\section{Step VII. Sephadex G-50 gel filtration}

The dissolved solution was subjected to Sephadex G-50 gel filtration. The absorbent equilibrated with distilled water was packed into a column $(1.0 \times 180 \mathrm{~cm})$. A part of the active solution was placed on the top of the column and was eluted with distilled water. Figure 2 shows a typical elution pattern of the active fraction. These active fractions were collected and excess water was completely evaporated off in vacuo at $50^{\circ} \mathrm{C}$, and then the dried sample (about $100 \mathrm{mg}$ ) was stored in

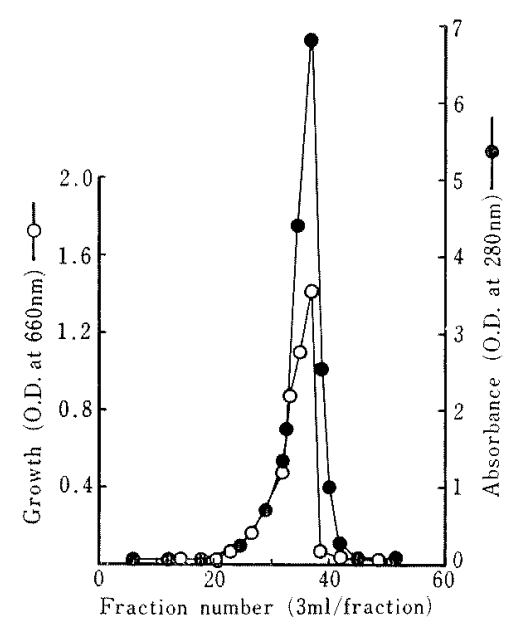

FiG. 2. Chromatography of Growth Effecting Substance on Sephadex G-50.

Chromatography was performed as stated in the text, and the activity was bioassayed under the standard assay conditions.

a desiccator.

\section{Properties of purified peptide}

Paper electrophoresis and bioautography. The dried powder was dissolved in a small volume of the same buffers used in electrophoresis. A sample solution was spread on paper (Toyo Roshi No. 51), $4.0 \mathrm{~cm}$ in width. Electrophoresis was carried out in each buffer at $5^{\circ} \mathrm{C}$ with $0.25 \mathrm{~mA} / \mathrm{cm}$ for $5 \mathrm{hr}$. After the

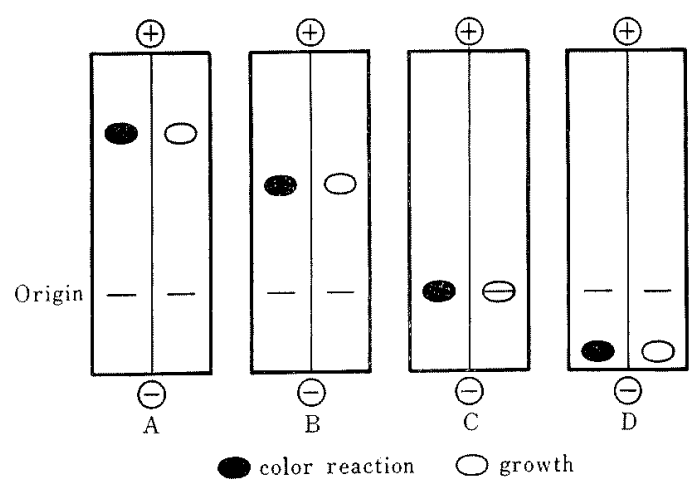

FIG. 3. Paper Electrophoresis and Bioautography of Purified Peptide.

Electrophoresis was carried out on paper at $5{ }^{\circ} \mathrm{C}$ with $0.25 \mathrm{~mA} / \mathrm{cm}$ for $5 \mathrm{hr}$. Peptide distribution was checked by staining with ninhydrin reagent.

A. Veronal buffer $(\mu=0.05, \mathrm{pH} 8.3) ; \mathrm{B}$, phosphate buffer $(\mu=0.05, \mathrm{pH} 6.8) ; \mathrm{C}$, pyridine: acetate: water $=$ $1: 10: 89(\mathrm{pH} 3.6) ; \mathrm{D}, 80 \%$ formate: acetate: water $=$ 5: 15:80(pH 1.9). 
run, the distribution of the peptide on the paper was shown by staining with ninhydrin and BPB reagent. As shown in Fig. 3, the peptide gave only one band in paper electrophoresis in each buffer, and $B$. cereus showed a good response to the single band on the bioautogram.

Absorption spectrum. The ultra violet absorption of the peptide was measured under two different conditions. From a spectrum, which had a maximum absorption at $275 \mathrm{~nm}$ in $0.1 \mathrm{~N} \mathrm{HCl}$, the specific extinction of $1.0 \%$ $(\mathrm{w} / \mathrm{w})$ solution at $280 \mathrm{~nm}\left(E_{1 \mathrm{~cm}}^{1 \%}\right.$ at $\left.280 \mathrm{~nm}\right)$ was calculated to be 11.9. From another spectrum, which was measured in $0.1 \mathrm{~N} \mathrm{NaOH}$, the tryptophan content was estimated to be one residue per a single molecule."

Molecular weight. The molecular weight of the peptide was estimated as approximately 8000 by Andrew's gel filtration method ${ }^{5 /}$ using pepsin, trypsin, cytochrome $\mathrm{C}$, coenzyme $\mathrm{A}$ (dimer) and vitamin $B_{12}$ as reference samples.

Isoelectric point. The isoelectric point was determined on the basis of the electrophoretic mobility of the peptide as a function of $\mathrm{pH}$. Paper electrophoresis was performed on Toyo Roshi No. 51 in $0.1 \mathrm{M}$-pyridine-acetate buffer, $\mathrm{pH} 3.5 \sim 5.5$, in $0.25 \mathrm{~mA} / \mathrm{cm}$ for $10 \mathrm{hr}$ at $5^{\circ} \mathrm{C}$. It was calculated to be $\mathrm{pH} 4.3$ from the plot of electrophoretic mobility in $0.1 \mathrm{M}$-pyridineacetate buffer against $\mathrm{pH}$ in the range of $3.5 \sim$ 5.5 .

Color reactions. Table I shows the color reactions of the peptide. The peptide was positive in such protein color reactions as Buiret, Xanthoprotein, Ninhydrin, ${ }^{8}$ and Folin ${ }^{8)}$ reactions. And the partially hydrolyzed peptide was negative in such sugar reactions as Elson-Morgan ${ }^{9)}$ and Anthrone ${ }^{9)}$ reactions.

Chemical composition. The peptide $(5 \mathrm{mg}$ each) was hydrolyzed with $6 \mathrm{~N} \mathrm{HCl}$ at $110 \pm 1{ }^{\circ} \mathrm{C}$ for 24 and $48 \mathrm{hr}$. Amino acids in the hydrolysate were measured by a Hitachi Amino Acid Analyzer KLA-3B by the method of Moore

Table II. Amino Acid Composition of Purified Peptide

\begin{tabular}{|c|c|c|}
\hline \multirow[t]{2}{*}{ Amino acid } & \multicolumn{2}{|c|}{$\begin{array}{l}\text { Numbers of amino acid per } \\
\text { mole of purified peptide }\end{array}$} \\
\hline & Calculated & Integral \\
\hline Asp & 9.6 & 10 \\
\hline Thr & 2.0 & 2 \\
\hline Ser & 2.7 & 3 \\
\hline Glu & 15.4 & 15 \\
\hline Pro & 5.4 & 5 \\
\hline Gly & 4.1 & 4 \\
\hline Ala & 2.5 & 3 \\
\hline 1/2 Cys & 4.9 & $5^{b 1}$ \\
\hline Val & 1.9 & 2 \\
\hline Met & 0.9 & 1 \\
\hline Ileu & 2.0 & 2 \\
\hline Leu & 2.9 & 3 \\
\hline Tyr & 0.9 & 1 \\
\hline Phe & 1.0 & 1 \\
\hline Try & - & $1^{c)}$ \\
\hline Lys & 5.5 & 6 \\
\hline His & 1.5 & 2 \\
\hline Arg & 3.6 & 4 \\
\hline
\end{tabular}

a) Based on a molecular weight of 8000 .

b) Estimated from the result of elementary analysis and Ellman reaction. ${ }^{71}$

c) Determined spectrophotometrically.

Table I. Color Reactions of Purified Peptide

The experiments were carried out according to ordinary methods.

\begin{tabular}{|c|c|c|c|}
\hline $\begin{array}{l}\text { Tested } \\
\text { reaction }\end{array}$ & Resultal & $\begin{array}{l}\text { Tested } \\
\text { reaction }\end{array}$ & Result \\
\hline Molisch & - & ElIman & + \\
\hline Anthrone & - & Ninhydrin & + \\
\hline Orcinol & - & Biuret & + \\
\hline Nelson-Somogyi & - & Xanthoprotein & + \\
\hline Elson-Morgan & - & Folin & + \\
\hline Fiske-Subbarow ${ }^{10\}}$ & - & Nessler & + \\
\hline
\end{tabular}

a. +, positive; -, negative. 
and Stein. ${ }^{11}$ The results are shown in Table II. Based on the above data that the molecular weight of the peptide is approximately 8000 , the total number of amino acids and the molecular weight of the peptide are calculated to be 70 and 8058 respectively. The result of elemental analysis indicated that the peptide consists of $\mathrm{C} 49.12 \%, \mathrm{H} 6.26 \%, \mathrm{~N} 16.44 \%$ and $\mathrm{S} 2.34 \%$.

$N$-Terminal amino acid. The N-terminal amino acid of the purified peptide was estimated by the DNP method. ${ }^{12}$ Solvent A (toluene: pyridine: 2-chloroethanol: $0.8 \mathrm{~N} \quad \mathrm{NH}_{4} \mathrm{OH}=$ $50: 15: 30: 30$ ) was used for the first dimension thin layer chromatography and solvent $B$ (chloroform: benzylalcohol: acetic acid $=70$ : $30: 3$ ) for the second one. The result strongly suggests that the $\mathrm{N}$-terminal amino acid of the peptide is glutamate.

\section{Effect of purified peptide concentration on} bacterial growth

The effect of purified peptide-concentration on the growth of $B$. cereus was tested. The result obtained is shown in Fig. 4 . The growth of $B$. cereus was greater with increasing concentrations of the added purified peptide.

Effect of purified peptide on the growth of $B$. cereus at different growth stages

The peptide at a concentration of $0.15 \mathrm{mg} /$

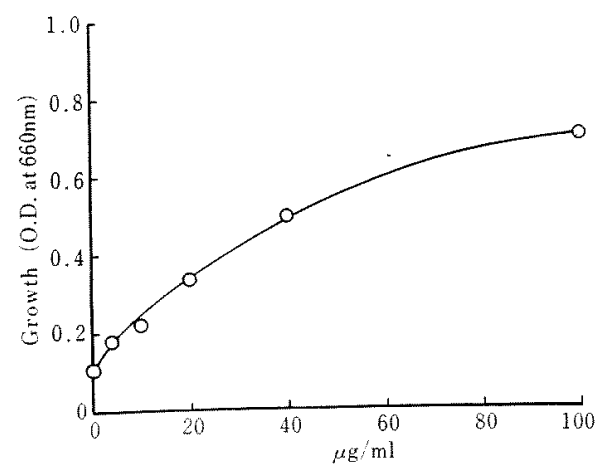

FIG. 4. Effect of Purified Peptide Concentration on Bacterial Growth.

Incubation was carried out under the standard bioassay conditions for $16 \mathrm{hr}$.
$0.1 \mathrm{ml}$ was added to the culture medium at different growth stages of $B$. cereus. A marked growth was immediately observed after the peptide was added at the lag phase or the initial stage of the exponential phase (Fig. 5). The addition of the peptide at the middle and last stages of the exponential phase had no influence on the growth.

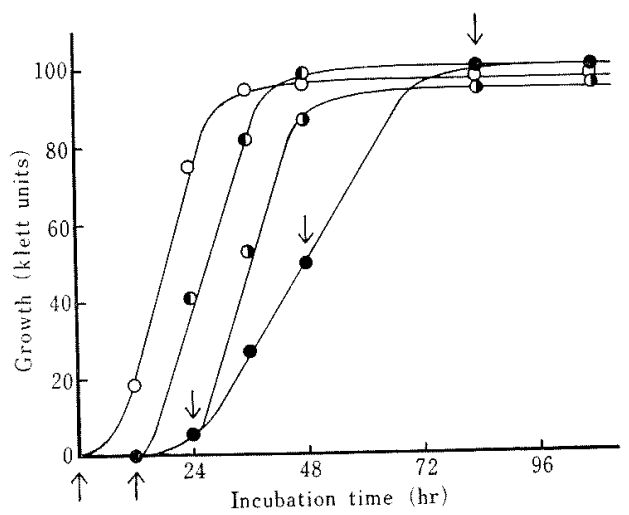

FIG. 5. Effect of Purified Peptide on the Growth of $B$, cereus at Different Growth Stages.

Purified peptide $(0.15 \mathrm{mg} / 0.1 \mathrm{ml})$ was added at the different growing stages as indicated by arrows: -0, $0 \mathrm{hr} ; \mathrm{O}-12 \mathrm{hr} ;-0,24 \mathrm{hr} ;-48 \mathrm{hr}$, $84 \mathrm{hr}$, none. The microorganisms were cultured for the specified period under the standard culture conditions.

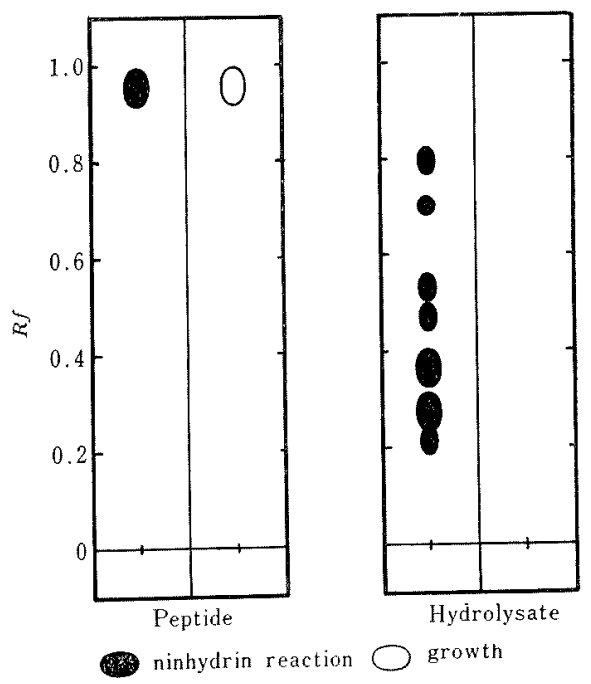

FIG. 6. Paper Chromatography and Bioautography of Hydrolyzed Peptide.

Paper chromatography and bioautography were performed as stated in the text. 
Effects of purified peptide and its hydrolysate on growth of $B$. cereus

The purified peptide $(5 \mathrm{mg})$ was hydrolyzed with $6 \mathrm{~N} \mathrm{HCl}$ at $110^{\circ} \mathrm{C}$ for $24 \mathrm{hr}$. The peptide and its hydrolysate were paper-chromatographed, and their biological activity was bioautographically tested. As shown in Fig. 6, the unhydrolyzed peptide gave only one spot which gave a marked growth owing to a growtheffecting substance, but the hydrolyzed peptide gave many invalid spots.

Stimulation of the microbial growth was also observed when the peptide (equivalent to $30 \mu \mathrm{g}$ peptide $/ \mathrm{ml}$ ) was added to the basal medium.

TABle III. EFfect of Hydrolyzed PEPTIDE ON GROWTH

Cultured for the specified period under the standard culture condition.

\begin{tabular}{lcc}
\hline $\begin{array}{c}\text { Culture } \\
\text { condition }\end{array}$ & \multicolumn{2}{c}{ Growth (klett units) } \\
& $24 \mathrm{hr}$ & $36 \mathrm{hr}$ \\
\hline Basal medium & 18 & 215 \\
$" \quad$ +Peptide & 134 & 247 \\
$" \quad$ +Hydrolysate & 46 & 226 \\
\hline
\end{tabular}

As shown in Table III, a stimulative effect on the growth of $B$. cereus after $24 \mathrm{hr}$-culture at $30^{\circ} \mathrm{C}$ was obtained only with the unhydrolyzed peptide, although no effect on the total growth after $36 \mathrm{hr}$.

Response of microorganisms to purified peptide

The response of various genera of microorganisms to the purified peptide was tested. The peptide $(30 \mu \mathrm{g} / \mathrm{ml})$ was added to the basal medium, and microorganisms were cultured at $30^{\circ} \mathrm{C}$ for the periods as indicated in Table IV. The extent of the growth of each strain was measured turbidimetrically. Almost all of the microorganisms tested showed a considerable growth in response to the added peptide. Especially, those belonging to the genera of Bacillus, Arthrobacter, and Xanthomonas showed a remarkable growth response.

\section{DISCUSSION}

Physiological activities of soybean proteins

Table IV. Response of Microorganisms to Purified Peptide

\begin{tabular}{|c|c|c|c|c|}
\hline \multirow{3}{*}{ Strain } & \multicolumn{4}{|c|}{ Growth (klett units) } \\
\hline & \multicolumn{2}{|c|}{$24 \mathrm{hr}$} & \multicolumn{2}{|c|}{$36 \mathrm{hr}$} \\
\hline & Added & Not added & Added & Not added \\
\hline Escherichia coli 26-A-1 & 151 & 120 & 151 & 125 \\
\hline Serratia marcescens IFO 3046 & 137 & 90 & 320 & 274 \\
\hline Proteus vulgaris IFO 3167 & 94 & 56 & 109 & 101 \\
\hline Bacillus cereus IFO 3001 & 148 & 4 & 223 & 151 \\
\hline B. aneurinolyticus & 90 & 35 & 108 & 89 \\
\hline B. megaterium NI 8100 & 23 & 4 & 164 & 76 \\
\hline B. natto Sawamura & 157 & 8 & 198 & 23 \\
\hline B. natto U. U. & 58 & 4 & 67 & 10 \\
\hline B. mesentericus var. flarus IFO 3028 & 57 & 40 & 145 & 124 \\
\hline B. subtilis IFO 3007 & 205 & 29 & 180 & 195 \\
\hline B. subtilis IFO 3037 & 87 & 20 & 126 & 20 \\
\hline B. subtilis IAM 1193 & 190 & 166 & 274 & 241 \\
\hline B. subtilis var. niger IFO 3214 & 121 & 57 & 120 & 71 \\
\hline B. brevis IFO 3331 & 9 & 1 & 38 & 2 \\
\hline B. pumilus IFO 3030 & 105 & 80 & 150 & 103 \\
\hline B. circulans IFO 3329 & 21 & 0 & 66 & 0 \\
\hline Micrococcus glutamicus No. 613 ATCC 13059 & 4 & 3 & 10 & 4 \\
\hline Arthrobacter oxydans IFO 12138 & 207 & 30 & 223 & 74 \\
\hline Brevibacterium divaricatum NRRL 2311 & 5 & 3 & 77 & 15 \\
\hline Xanthomonas malvecearum IFO 3383 & 204 & 86 & 182 & 181 \\
\hline Acetobacter aceti IFO 3284 & 2 & 1 & 2 & 1 \\
\hline
\end{tabular}


have been investigated and some biological active substances such as trypsin inhibitors, ${ }^{13 \sim 16)}$ hemagglutinins, ${ }^{17 \sim 19)} \quad \beta$-amylase, ${ }^{20)} \quad$ lipoxygenase, ${ }^{21,22)}$ protease ${ }^{23)}$ and chalconflavanone isomerase $^{24}$ have been isolated. It was also reported by Thompson et al. ${ }^{25,26)}$ that two dipeptides of glutamic acid, $\gamma$-glutamyltyrosin and $\gamma$-glutamylphenylalanine was found in the non-protein nitrogen fraction of soybeans. Bergey ${ }^{27}$ reported that the growth of Bacillus species and other bacteria was marked on a soybean agar slant. However, the chemical properties and the physiological roles of the active substances in soybean have little been investigated. Nakagaki and Hirano' recently reported that an aqueous extract of soybean seeds showed a growth promoting activity for $L$. acidophilus and $L$. bulgaricus and that the activity was mainly due to adenine, guanosine and L-tryptophan. It was also reported by Busta and Schroder ${ }^{2}$ that some soybean proteins had stimulative effects on the growth of Clostridium perfringens.

In this paper, therefore, the purification of the effective substances on the growth of Bacillus species was undertaken and the properties of the purified peptide were investigated. This purified peptide was found to differ from the peptidic substance from soybean Miso which shows a remarkable growth effect especially on Pediococcus halophilus. ${ }^{3 \text { ' }}$ The present result that the purified peptide was negative in sugar reactions as shown in Table I suggests that the peptide is composed of amino acids. When the peptide was completely hydrolyzed in $6 \mathrm{~N} \mathrm{HCl}$ for $24 \mathrm{hr}$ the activity on $B$. cereus almost disappeared (Fig. 6). When the peptide or its hydrolysate was added to the basal medium the peptide showed more stimulative effect than the hydrolysate (Table III). These findings suggest that there is an active center in the molecule of this peptide for the activity on $B$. cereus. Hence, it is necessary to partially hydrolyze the peptide using such proteolytic enzymes as pepsin, trypsin, etc.

When the purified peptide was added to the culture medium at the first stage, the lag phase or the initial stage of the exponential phase, the stimulating effect on microbial growth was observed (Fig. 5). As shown in Fig. 5, it was observed by the addition of the peptide that the lag period of the growth of $B$. cereus was shortened. It seems obvious that the peptide plays a significant role during the initial stage of microbial growth. Investigations on the physiological roles of the peptide during the growth are under progress in our laboratory. It is also interesting that a peptide-like substance having biological activities on the growth of microorganisms was observed in various naturally occuring materials such as koji extracts, carrot extracts, corn gluten meal and cotton seed flour.

Acknowledgement. The authors wish to thank Mr. A. Saeki for his technical assistance during the course of this investigation.

\section{REFERENCES}

1) T. Nakagaki and S. Hirano, Agr. Biol. Chem., 34, 1580 (1970).

2) F. F. Busta and D. J. Schroder, Appl. Microbiol., 22, 177 (1971).

3) T. Takeuchi and H. Yoshii, J. Ferment. Technol, 51, 170 (1973).

4) T. W. Goodwin and R. A. Morton, Biochem. J., 40, 628 (1946).

5) P. Andrews, ibid., 91, 222 (1964).

6) "Methods in Enzymology," Vol. III, ed. by G. Glick and N. O. Kaplan, Academic Press Inc., New York, N.Y., 1957, p. 468.

7) G. L. Ellman, Arch. Biochem. Biophys., 82, 70 (1959).

8) O. H. Lowry, N. J. Rosebrough, A. L. Farr and R. J. Randall, J. Biol. Chem., 193, 265 (1951).

9) "Methods in Carbohydrate Chemistry," Vol. I, ed. by R. L. Whistler and M. L. Wolfrom, Academic Press Inc., New York, N.Y., 1962, p. 475.

10) C. H. Fiske and Y. Subbarow, $J$. Biol. Chem., 66, 375 (1925).

11) "Methods in Enzymology," Vol. VI, ed. by G. Glick and N. O. Kaplan, Academic Press Inc., New York, N.Y., 1963, p. 819.

12) "Techniques of Thin-Layer Chromatography," ed. by G. Pataki, Humphrey Science Publishers Inc., Michigan, 1966, p. 126.

13) J. J. Rackis and R. L. Anderson, Biochem. Biophys. Res. Commun., 15, 230 (1964).

14) M. Kuniz, J. Gen. Physiol., 30, 311 (1947).

15) Y. Birk, A. Gertler and S. Khalef, Biochem. J., 
87, 281 (1963).

16) M. Yamamoto and T. Ikenaka J. Biochem. (Japan), 62, 141 (1967).

17) R.H. Stead, H. J. H. Meulenaere and G. V. Quicke, Arch. Biochem. Biophys., 113, 703 (1966).

18) H. Lis, N. Sharon and E. Katchalski, J. Biol. Chem., 241, 684 (1966).

19) J. J. Rackis, H. A. Sasame, R. L. Anderson and A. K. Smith, J. Amer. Chem. Soc., 81, 6265 (1959).

20) A. Gertler and Y. Birk, Biochem. J., 95, 621 (1965)

21) H. Theorell, R. T. Holman and A. Akeson, Acta Chem. Scand, 1, 571 (1947).
22) H. Mitsuda, K. Yasumoto, A. Yamamoto and T. Kusano, Agr. Biol. Chem., 31, 115 (1967).

23) J. Weil, A. Pinsky and S. Grossman, Cereal Chem., 43, 392 (1966).

24) E. Moustafa and E. Wong, Phytochem., 6, 625 (1967).

25) C. J. Morris and J. F. Thompson, Biochemistry, 1, 706 (1962).

26) T. Kasai, Y. Ishikawa and Y. Obata, Agr. Biol. Chem., 30, 979 (1966).

27) "Bergey's Manual of Determinative Bacteriology," 7 ed., ed. by R. S. Breed, E. G. D. Murray and N. R. Smith, The Williams and Wilkins Company, 1957, p. 613. 